Dragan Kalaba, zamenik Višeg javnog tužioca u Čačku

\title{
DELO MALOG ZNAČAJA Zakonska rešenja, uslovi primene i sudska praksa
}

\begin{abstract}
SAŽETAK: Pozitivno krivično zakonodavstvo Srbije na jasan način reguliše pojam krivičnog dela. Postoje određene životne situacije u krivično-pravnom smislu da radnja učinioca predstavlja krivično delo, ali se pod određenim uslovima, ima smatrati da krivično delo ne postoji. To su osnovi isključenja krivičnog dela, a jedan od njih je i delo malog značaja predviđen u čl. 18. Krivičnog zakonika. Istorija pojma krivičnog dela i njegovih elemenata je istovremeno $\mathrm{i}$ istorija dela malog značaja.

Ključne reči: krivično delo, osnovi isključenja krivičnog dela, neznatna društvena opasnost, delo malog značaja, uslovi za primenu, istorijat
\end{abstract}

\section{Uvod}

Stupanjem na snagu Krivičnog zakonika 1. januara 2006. godine, između ostalog, u čl. 14. je na nov način regulisan pojam krivičnog dela.

Prema navedenoj odredbi, krivično delo je prvo, ono delo predviđeno $u$ Zakonu kao krivično delo, drugo, isto je protivpravno i treće, skrivljeno je. To znači da je zakonodavac predvideo šta se, kao devijantno ponašanje u društvu, ima smatrati krivičnim delom. Sa druge strane postoji interes društva, a što je zakonodavac i propratio, da se za određeno devijantno ponašanje pojedinca, a koje predstavlja krivično delo, smatra da isto krivično delo ne postoji, a to dalje znači da se ne procesuira niti se određuju krivične sankcije. To su osnovi 
isključenja postojanja krivičnog dela. Jedan od tih osnova je i delo malog značaja predviđen u čl. 18. KZ.

Do stupanja na snagu Krivičnog zakonika, dakle u Osnovnom krivičnom zakonu i Krivičnom zakonu SRJ, nije zakonski bilo predviđeno koji je elemenat krivičnog dela (čl. 8. st. 1. OKZ - KZ SRJ) isključen, da bi postojala neznatna društvena opasnost (čl. 8. st. 2). Zbog toga su se vodile teorijske rasprave o tome koji elemenat krivičnog dela ne postoji, pa da se ima primeniti institut neznatne društvene opasnosti.

Sadašnje zakonsko rešenje je jasno: kada je isključena protivpravnost kao bitan elemenat krivičnog dela, krivičnog dela nema i ima se primeniti odredba čl. 18. st. 2. KZ. Sadržina čl. 18. st. 2. KZ glasi: delo je malog značaja ako je stepen krivice nizak, ako su štetne posledice odsutne ili neznatne i ako opšta svrha krivičnih sankcija ne zahteva izricanje krivičnih sankcija. U stavu 1. toga člana je predviđena opšta odredba a to je: „nije krivično delo ono delo koje, iako sadrži obeležja krivičnog dela, predstavlja delo malog značaja”. U stavu 3. istog člana je navedeno: „odredbe stava 1. i 2. ovog člana mogu se primeniti na krivična dela za koje je propisana kazna zatvora do tri godine ili novčana kazna, s tim da Zakonom o izmenama i dopunama Krivičnog zakonika, institut dela malog značaja se može primeniti na krivična dela za koja je propisana kazna zatvora do pet godina, a ostaje kako je prvobitno regulisano $\mathrm{i}$ za krivična dela za koja je propisana i novčana kazna (naravno, bez ograničenja u pogledu visine kazne).

Kada je u pitanju stav zakonodavstva o ovom pravnom institutu, uočljivo je da do stupanja na snagu Krivičnog zakonika, u ranijem Osnovnom krivičnom zakonu, odnosno Krivičnom zakonu SRJ, u istom članu (čl. 8) je regulisan pojam krivičnog dela, u stavu 1 , a u stavu 2. je regulisan pomenuti institut kao neznatna društvena opasnost koja isključuje postojanje krivičnog dela. Sadašnje rešenje u Krivičnom zakoniku, posebno u čl. 14. je regulisan pojam krivičnog dela, a posebno u čl. 18. je regulisan osnov isključenja postojanja krivičnog dela, a to znači da je time dat odgovarajući značaj tome institutu kao zakonodavno rešenje i kao rešenje za primenu u sudskoj praksi.

\section{Uslovi za primenu čl. 18. st. 2. KZ}

U konkretnoj krivično-pravnoj situaciji, radi ocene da li ima mesta primeni dela malog značaja, a to znači da krivično delo (učinjeno) i ne postoji, moraju se ostvariti tri uslova:

- da je stepen krivice nizak,

- da su štetne posledice odsutne ili neznatne, 
- da opšta svrha krivičnih sankcija ne zahteva izricanje krivičnih sankcija.

Kako je primena instituta iz čl. 18. st. 2. KZ fakultativna, to znači da se ostvarenje sva tri uslova mora utvrđivati u svakom konkretnom slučaju. Kada je u pitanju stepen krivice, mora se poći od krivice kao bitnog uslova za postojanje krivičnog dela, kako je predviđeno u čl. 14. st. 1, a zatim i u čl. 22. KZ kojim je određeno „kada krivica postoji”, a takođe i od sadržine čl. 25. KZ (regulisan je umišljaj) i od čl. 26. KZ (regulisan je nehat).

Stepen krivice, kao nizak mora se utvrđivati sa jedne strane, sa aspekta subjektivnog elementa krivičnog dela i sa druge strane sa aspekta objektivnih elemenata krivičnog dela, a što je u međusobnoj zavisnosti.

To dalje znači da se odredba člana 18. st. 2. KZ može primeniti kako za nehatna krivična dela tako i za krivična dela izvršena sa umišljajem. Praksa pokazuje, da u ogromnom broju slučajeva, a u kojima je primenjen pomenuti institut, radi se o nehatnim krivičnim delima.

$\mathrm{Na}$ osnovu navedenog, smatram da navedeno rešenje u čl. 18. st. 2. KZ je nejasno i neprecizno.

Kako je u čl. 22. st. 2. KZ izričito predviđeno da postoji krivično delo koje je izvršeno nehatno (kao oblik krivice) ukoliko je to Zakon izričito predvideo, to bi bilo logično da u sadašnjem čl. 18. st. 2. KZ bude navedeno da delo malog značaja postoji ako je učinjeno nehatno, ako su štetne posledice odsutne ili neznatne i ako opšta svrha krivičnih sankcija ne zahteva izricanje krivičnih sankcija, a za dela učinjena sa umišljajem, ako je stepen krivice nizak, a štetne posledice su odsutne ili neznatne i ako opšta svrha krivičnih sankcija ne zahteva izricanje krivičnih sankcija. Naravno, navedeni predlog podrazumeva da ostaje sadašnje rešenje predviđeno u čl. 18. st. 3. KZ, a to je visina propisane kazne zatvora do pet godina odnosno novčana kazna. To znači, da u svakom konkretnom slučaju datog krivično-pravnog događaja, treba oceniti, a na bazi dokaza, ima li mesta primeni navedenog instituta. U svakom slučaju treba da se radi o gotovo beznačajnom ili bagatelnom krivičnom delu za koje država nije zainteresovana za gonjenje i dalje procesuiranje.

Kada je reč o posledici krivičnog dela, kao drugom uslovu za primenu navedenog instituta, isti je postavljen alternativno, a to je da su štetne posledice odsutne, a to znači da do nastupanja posledica nije ni došlo (krivična dela ugrožavanja) ili su neznatne, a to znači da izvršenjem krivičnog dela povrede, nastupela posledica dela je neznatna. Naravno, ako je štetna posledica nastupila, onda za pojam štete imaju se primeniti opšti instituti građanskog prava, posebno u delu vrste štete, njenog obima i na kraju da se zaključi da li su iste neznatne. I ovde se mora poći od date situacije, sa aspekta celog krivično-pravnog događaja i ceniti da su nastupele štetne posledice neznatne. 
Treći uslov za primenu instituta malog značaja je da opšta svrha krivičnih sankcija ne zahteva izricanje krivičnih sankcija, a to je u stvari primena odredbe čl. 4. st. 2. KZ. To dalje znači, da u konkretnom slučaju, mora se poći od tzv. specijalne prevencije (čl. 42. KZ) i od tzv. generalne prevencije (čl. 4. st. 2. KZ). Kako je suština primena instituta dela malog značaja utvrđivanje postojanje uslova sa aspekta subjektivnog elementa krivičnog dela (krivica) tako i sa aspekta objektivnog elementa krivičnog dela (u odnosu na posledice), to se mora ceniti i svrha primene navedenog instituta ne izricanjem krivičnih sankcija jer je time sprečeno da konkretni učinilac krivičnog dela vrši buduća krivična dela, da se time pozitivno utiče na druga lica da ne čine krivično delo, da se izražava na taj način društvena osuda učinjenog krivičnog dela i konačno da se primenom čl. 18. st. 2. KZ utiče na suzbijanje dela kojima se povređuju ili ugrožavaju vrednosti zaštićene krivičnim zakonodavstvom.

Za razliku od ranijeg rešenja u OKZ i KZJ, sada je u čl. 18. st. 3. KZ predviđeno da se institut dela malog značaja može primeniti na krivična dela za koja je propisana kazna zatvora do pet godina ili novčana kazna. Upravo primena ranije odredbe čl. 8. st. 2. OKZ (KZJ) je stvorila određenu veću slobodu u primeni ovog instituta i za teža krivična dela s obzirom da nije bila predviđena granica u pogledu visine kazne zatvora za koje se može primeniti.

Kako je suština dela malog značaja kao osnova isključenja krivičnog dela, njegova primena za lakša, beznačajna, bagatelna krivična dela, to je pravilno zakonodavac predvideo okvir za njegovu primenu, a to je gornja granica visine kazne zatvora za krivično delo ili pak novčana kazna, čime je i ograničena primena navedenog instituta.

\section{Istorijat instituta dela malog značaja}

Istorijski prikaz sadašnjeg instituta dela malog značaja se mora posmatrati u neraskidivoj vezi sa pojmom krivičnog dela, onako kako je dat i zakonski normiran u datim društveno-ekonomskim prilikama pa tako:

- U Krivičnom zakoniku Kraljevine Jugoslavije od 27. januara 1929. godine, u glavi prvoj, uvodne odredbe, paragrafu 1. je predviđeno da „niko ne može biti kažnjen za delo za koje nije Zakon, pre nego što je učinjeno propisao da će se i kako će se kazniti onaj koji ga učini”. Dalje, u paragrafu 15. je izvršena deoba krivičnih dela, a u paragrafu 24. je predviđeno: „ono delo, koje neko učini u nužnoj odbrani nije protivpravno". U paragrafu 15. je predviđeno da neće biti odgovoran za krivično delo ... usled postojanja zablude...

Ono što je interesantno, u Krivičnom zakoniku Kraljevine Jugoslavije nije posebno predviđen osnov isključenja društvene opasnosti krivičnog dela 
odnosno dela malog značaja. Jedino je u paragrafu 23. predviđeno: „da nema krivičnog dela ako propisi javnog ili privatnog prava isključuju protivpravnost delanja”. To znači da se radi o upućujućim propisima, a prema dostupnoj literaturi i sudskoj praksi, isto se odnosi na: a) isključenje dela učinjeno u službi, b) usled zakonitog vršenja profesije ili zanata, c) ostvarenje disciplinske vlasti, d) ostvarenje svog prava, e) u slučaju povrede ili uništenja svojih pravnih ili ličnih dobara.

Dakle, institut dela malog značaja, bilo izričito, bilo prećutno (upućujući propisi), u Krivičnom zakoniku Kraljevine Jugoslavije nije predviđen.

- Krivični zakonik - opšti deo koji je stupio na snagu 12. februara 1948. godine (Službeni list FNRJ, broj 106. od 13. decembra 1947. godine), u čl. 1. je propisao da „krivično zakonodavstvo FNRJ ima zadatak da određivanjem krivičnih dela i propisivanjem kazni, vaspitno-popravnih i zdravstveno-zaštitnih mera, koji se primenjuju u zakonom određenom postupku, štiti od društveno opasnih dela, narodnu državu zasnovanu na tekovinama Narodno-oslobodilačke borbe, njen pravni poredak, njenu socijalističku izgradnju i ličnost $\mathrm{i}$ pravo njenog građanina”. U čl. 3. je regulisano: „nema krivične odgovornosti za delo koje nije društveno opasno, društveno je opasno delo koje ugrožava ili narušava državno i društveno uređenje, nezavisnost i bezbednost FNRJ, ličnost građanina, njihova prava i prava društvenih organizacija kao i uopšte pravni poredak utvrđen Saveznim Ustavom i Ustavima narodnih republika." U čl. 5. je regulisano: „nema krivične odgovornosti za delo koje, iako sadrži obeležja krivičnog dela određenog u Zakonu, predstavlja neznatnu društvenu opasnost zbog očigledno malog značaja i zbog neznatnosti ili odsutnosti štetnih posledica."

Dakle, prema tadašnjoj nauci krivičnog prava i zakonskim rešenjima, krivično delo se pojavljuje u svom suštinskom materijalnom sadržaju pa je to društveno opasno delo, odnosno delo upravljanja protiv narodne države i njenih osnovnih temelja.

I u tadašnjim uslovima, zauzet je stav da ako stvarna sadržina jednog u Zakonu određenog krivičnog dela ne predstavlja dovoljnu društvenu opasnost za stvarno postojanje krivične odgovornosti učinioca, Zakonik propisuje isključenje krivične odgovornosti. U tom pogledu se propisuje da delo neznatne društvene opasnosti, koja se izražava u očigledno malom značaju toga dela i u neznatnosti ili nepostojanju njegovih štetnih posledica, nije dovoljno za postojanje krivične odgovornosti, iako je takvo delo formalno određeno kao krivično delo u Zakonu. Ovakvo delo nije stvarno krivično delo, iako ono to formalno jeste, jer njegova unutrašnja materijalna sadržina nije takva da može ispuniti njegovu krivičnu sadržinu i zahtevati krivičnu odgovornost. 
To znači da, kada su ispunjeni uslovi iz čl. 3. Krivičnog zakonika, u vezi sa neznatnom društvenom opasnošću krivičnog dela, tada nema krivične odgovornosti, a za razliku od sadažnjeg rešenja kojim je predviđeno da tada nema krivičnog dela.

- U Krivičnom zakoniku - opšti deo (Službeni list FNRJ, broj 13. od 9. marta 1951. godine), koji je stupio na snagu 1. jula 1951. godine, u čl. 4. je dat pojam krivičnog dela, da je „krivično delo društveno opasno delo čija su obeležja određena Zakonom, nije krivično delo ono delo koje, iako sadrži obeležja krivičnog dela određena Zakonom, predstavlja neznatnu društvenu opasnost zbog malog značaja i zbog neznatnosti ili odsutnosti štetnih posledica".

\section{Delo malog značaja u sudskoj praksi}

Kako je institut dela malog značaja fakultativni osnov za primenu, smatram, da treba navesti brojne slučajeve iz sudske prakse iz kojih se vidi primena pomenutog instituta $\mathrm{i}$ da se na takav način pomogne učesnicima sudskog postupka u njegovoj primeni.

\section{Starija sudska praksa}

- Činjenica da je neznatna šteta pričinjena delom koje sadrži obeležja krivičnog dela određena zakonom, nije razlog za primenu čl. 4. KZ kada to delo nije malog značaja i nije zbog toga neznatne društvene opasnosti (VSJ KZ 5/56) ${ }^{1}$.

- Postoji povreda Krivičnog zakona kada se okrivljeni presudom oglašava krivim za delo koje ima obeležja krivičnog dela određenog u Zakonu ali predstavlja neznatnu društvenu opasnost u smislu čl. 4. KZ. Drugostepeni sud može preinačiti presudu i okrivljenog osloboditi od optužbe kada je prvostepeni sud utvrdio okolnosti na osnovu kojih se pouzdano zaključuje da delo predstavlja neznatnu društvenu opasnost (VSH Kž 347/57)2.

- I pored neznatnosti posledica, delo koje ima zakonska obeležja krađe, a izvršeno je na način kojim se odlikuje teška krađa po čl. 250. KZ, nije delo malog značaja, te ne predstavlja neznatnu društvenu opasnost u smislu čl. 4. istog Zakona (VSV K 1000/58).

${ }^{1}$ Pregled sudske prakse - krivično pravo - I deo, obradio Zoran Jovičić, Užice, 1973, izdanje autora.

${ }^{2}$ Isto.

${ }^{3}$ Isto. 
- Ne može se uzeti da predstavlja neznatnu društvenu opasnost zbog malog značaja i zbog odsutnosti štetnih posledica (čl. 4. st. 2. KZ) takva radnja izvršenja krivičnog dela koja se sastoji u falsifikovanju službenih dokumenata u izvršenju isplata službenim licima na osnovu takvih dokumenata (VSJ Kž 24/64)

- Krivično delo teške krađe iz čl. 250. KZ ne može se smatrati kao delo koje predstavlja neznatnu društvenu opasnost (VSV Kž 60/69) ${ }^{5}$.

- Za ocenu da li se radi o neznatnosti štetnih posledica u smislu neznatne materijalne štete odlučno je i materijalno stanje oštećenog, pa i tu okolnost treba u postupku utvrđivati (OS Zagreb Kž 189/72) .

- Gde su se štetne posledice izrazile u materijalnoj šteti, ne može se bez utvrđivanja štete zaključiti da se radi o neznatnosti štetnih posledica, kao jednom od uslova za primenu čl. 4. st. 2. KZ (OS Zagreb Kž 218/72)7.

- Ne može se oceniti delom koje predstavlja neznatnu društvenu opasnost u smislu čl. 4. st. 2. KZ aktivnost optuženog koji je provalio u prodavnicu s namerom da uzme makar samo nešto prehrambenih artikala i prisvojio samo pet komada salame, ako se ima u vidu opasan i drzak način provale noću u prodavnicu, pogotovo kada se ima u vidu da je optuženi već više puta osuđivan (VSH Kž 899/72).

- U predmetu je utvrđeno da je okrivljeni pomoću materijala za koji je smatrao da je odgovarajući i specijalno modificiranih kalupa pravio lažan novac koji je trebalo da imitira pravi novac, a sve to da bi se isti kao pravi mogao staviti u opticaj. S obzirom na izneto, ponašanje okrivljenog koji nije u skladu sa pravnim i društvenim normama, a uz postojanje svesti da pravi lažan novac i namere za upotrebom lažnog novca kao pravog, ima karakter protivpravnosti odnosno sadrži u sebi formalnu stranu društvene opasnosti dela čija su zakonska obeležja predviđena u čl. 221. st. 1. KZ. Međutim, kada se imaju u vidu način izrade, količina izrađenih lažnih novčanih apoena i rezultat protivpravne delatnosti okrivljenog pa i posledice te delatnosti, jer je nesumnjivo utvrđeno da napravljeni lažni novac od $3 \mathrm{kom}$. po jedan dinar nije upotrebljen u prometu kao merilo vrednosti već je bačen zbog savitljivosti, odnosno lakog uočavanja i da je to neuspela imitacija pravog novca, onda delo okrivljenog predstavlja neznatnu društvenu opasnost zbog malog značaja takve delatnosti i zbog odsutnosti štetnih posledica (VSS Kž 1294/72)

\footnotetext{
${ }^{4}$ Isto.

${ }^{5}$ Isto.

${ }^{6}$ Isto.

${ }^{7}$ Isto.

${ }^{8}$ Krivični zakonik - sudska praksa, odabrao Zoran Jovičić, Užice, 1999, izdanje autora.

${ }^{9}$ Isto.
} 
- Rešenjem prvostepenog suda, okrivljenom, inače učitelju osnovne škole, zbog krivičnog dela iz čl. 142. st. 1. KZ na štetu maloletnika, izrečena je sudska opomena. Drugostepeni sud je uvažio žalbu privatnog tužioca i okrivljenog oglasio krivim zbog krivičnog dela iz čl. 142. st. 1. KZ i osudio na uslovnu kaznu. To iz razloga što je fizički obračun nastavnika prema učenicima zbog nediscipline protivan pravilima pedagogije i vaspitanja učenika i zato se odgovornost okrivljenog u svojstvu nastavnika ukazuje mnogo širom. Takav se slučaj ne može podvesti pod primenu propisa čl. 4. st. 2. KZ (OKR sud Rijeka Kž 339/72) ${ }^{10}$.

- Drugostepeni sud nije prihvatio pravno shvatanje okrivljenog da krivično delo iz čl. 314a. st. 3. u vezi st. 1 . KZ u konkretnom slučaju predstavlja neznatnu društvenu opasnost zbog malog značaja i zbog neznatnosti ili odsutnosti štetnih posledica. To iz razloga što je okrivljeni u preduzeću obavljao funkciju finansijskog direktora, pa davanjem iznosa od 1.092,00 dinara na teret preduzeća jednom radniku, pa makar on za preduzeće bio beznačajan, ne može se smatrati samo finansijskim prekršajem (OKR Sud Rijeka Kž 237/73) ${ }^{11}$.

- Propis čl. 4. st. 2. KZ može doći do primene kod bilo kog krivičnog dela kod kojeg su ispunjeni zakonski uslovi. Da li ima mesta primeni toga člana zavisi od svestrane ocene mnogobrojnih i raznovrsnih okolnosti i činjenica objektivne i subjektivne prirode. Svaka parcijalna ocena stvari, posebno propuštanje da se delo i učinilac sagledaju u celini može dovesti do pogrešnih odluka koje nisu u skladu sa sadržinom odredbe čl. 4. st. 2. KZ. U konkretnom slučaju, okrivljeni je prisvojio u svojstvu studenta - saobraćajnog milicionera 90,00 dinara, te bio optužen za krivično delo iz čl. 322. st. 1. KZ. Okrivljeni je za vreme izvršenja krivičnog dela bio student, a u vreme suđenja završio Višu ekonomsku školu i stekao naziv ekonomiste, rođen je 1955, da je na početku svog životnog puta, pa s obzirom na svoje zanimanje, činjenica osuđivanosti za krivično delo pronevere i te kako ima uticaja kako na mogućnost zaposlenja tako i na dalji život u najširem smislu. Okrivljeni je inače apsolutno neporočan, a šteta iznosi samo 90,00 dinara, pa kada su u sukobu dvaju interesa, s jedne strane neznatnost stečene društvene imovine i posledice koje bi osuda imala za dalji život okrivljenog sa druge strane, na stanje stvari ukazuje se zaista da je delo okrivljenog malog značaja i sa neznatnim društvenim posledicama, pa predstavlja neznatnu društvenu opasnost (OKR Sud Split, Kž 485/73) (2) $^{2}$.

- Primena čl. 4. st. 2. KZ nije ograničena samo na krivična dela za koje je Zakon propisao lakše kazne (OKR Sud u Nišu, Kž 317/76) ${ }^{13}$.
${ }^{10}$ Isto.
${ }^{11}$ Isto.
${ }^{12}$ Isto.
${ }^{13}$ Isto. 
- Neosnovano je stanovište da sud može kod svih krivičnih dela iz čl. 170. st. 1. KZ primenom čl. 4. st. 2. KZ okrivljenog na osnovu čl. 321. t. 1. ZKP osloboditi od optužbe a sa obrazloženjem da to delo predstavlja neznatnu društvenu opasnost zbog malog značaja i odsutnosti štetnih posledica. Društvena opasnost tih dela je u takvom ponašanju nekoga prema drugome koje je protivno moralnim i etičkim shvatanjima kao i opšteusvojenim pravilima ponašanja. Ovim se krivičnim delima često zadire u osetljivu sveru dostojanstva i osećaja časti i unutrašnjeg mira pojedinca, takvi postupci često deluju na drugog ponižavajuće i to je takva štetna posledica tih krivičnih dela koja se ne može zanemariti, pa je potrebno članove društva od takvih postupaka zaštititi. Zbog toga se ne mogu na sva krivična dela uvrede, koje inače sadrže elemente tog dela primeniti propis čl. 4. st. 2. KZ i doneti presude na osnovu čl. 321. t. 1. ZKP (OKR Sud Karlovac Kž 2/77) $)^{14}$.

\section{Novija sudska praksa}

- Presudom drugostepenog suda povodom žalbe branioca okrivljene preinačena je prvostepena presuda (kojom je okrivljena oglašena krivom zbog krivičnog dela lake telesne povrede iz čl. 122. st. 1. KZ) tako da se okrivljena primenom odredbe čl. 355. t. 1. ZKP u vezi sa čl. 18. KZ oslobađa od optužbe da je izvršila krivično delo opisano u izreci prvostepene presude. Dokazima je utvrđeno da je u prethodnom događaju privatni tužilac vređao sina okrivljene, pa imajući u vidu utvrđene činjenice, očigledno je da je okrivljena reagovala na napred navedeni način jer je bila izazvana nepristojnim i grubim ponašanjem privatnih tužilaca koji su najpre vređali a potom udarili njenog sina, pa iz tih razloga je očigledno da je stepen krivice okrivljene nizak, da su štetne posledice neznatne, a s obzirom na sve okolnosti učinjenog dela nije opravdano da se okrivljenoj izrekne krivična sankcija. To znači da je Okružni sud ocenio primenom čl. 18. KZ da postupak okrivljene iako sadrži obeležje krivičnog dela lake telesne povrede iz čl. 122. st. 1 . KZ da to delo nije krivično delo jer iz napred navedenih razloga predstavlja delo malog značaja, pa primenom čl. 18. KZ i po službenoj dužnosti odlučeno je kao u izreci (Presuda Opštinskog suda u G. Milanovcu K 406/08 od 5. februara 2009. i presuda Okružnog suda u Čačku Kž 164/09 od 27. marta 2009) ${ }^{15}$.

- Kada se okrivljeni oglasi krivim zbog krivičnog dela neovlašćeno nabavljanje, držanje i nošenje vatrenog oružja i municije iz čl. 33. st. 2. Zakona o oružju i municiji, a u opisu radnje izvršenja krivičnog dela u izreci se navede

${ }^{14}$ Isto.

${ }^{15}$ Sudske odluke Okružnog suda u Čačku - krivična materija (1999-2009. god.) - treća knjiga, Čačak, 2010, izdanje autora. 
da je nabavio, držao i nosio jedan metak kalibra $12,7 \mathrm{~mm}$, a potom u obrazloženju presude se navede da nema krivičnog dela zbog primene čl. 8. st. 2. OKZ, tada je učinjena bitna povreda odredaba krivičnog postupka iz čl. 368. st. 1. t. 11. ZKP (Presuda Okružnog suda u Čačku K 126/04 od 30. decembra 2004. i rešenje Vrhovnog suda Srbije Kž 807/05 od 25. maja 2005) ${ }^{16}$.

- Ne može se prihvatiti pravni stav prvostepenog suda da u radnjama okrivljenog nema elemenata krivičnog dela zloupotreba ovlašćenja u privredi iz čl. 139. st. 3. KZS, jer se radi o krivičnom delu malog značaja i neznatnoj opasnosti primenom čl. 8. st. 2. KZJ (Presuda Opštinskog suda u Čačku K 124/99 od 24. decembra 1999. i rešenje Okružnog suda u Čačku Kž 275/00 od 28. septembra 2000) ${ }^{17}$.

- U radnjama okrivljenog koji je kritičnom prilikom omogućio svedoku uživanje opojne droge tako što mu je dao dve tablete ,rivotrila” koju je svedok na licu mesta popio stiču se elementi krivičnog dela omogućavanje uživanja opojnih droga iz čl. 247. st. 1. KZ. Neosnovano se navodi u žalbi branioca okrivljenog da okrivljeni nije izvršio predmetno krivično delo jer ima mesta primeni čl. 18. KZ s obzirom da se radi o maloj količini opojne droge, a zbog toga što količina opojne droge nije bitan elemenat krivičnog dela iz čl. 247. st. 1. KZ. Sa druge strane, isti okrivljeni je istom presudom proglašen krivim i zbog krivičnog dela neovlašćena proizvodnja, držanje i stavljanje u promet opojnih droga iz čl. 246. st. 1. KZ jer je drugookrivljenom neovlašćeno prodao 75 kapsula „trodona”, pa stepen krivice okrivljenog nije nizak i nisu ispunjeni uslovi iz čl. 18. KZ (Presuda Okružnog suda u Čačku K 119/07 od 17. januara 2008. i presuda Vrhovnog suda Srbije Kž 475/08 od 14. aprila 2008) ${ }^{18}$.

- Kada je okrivljeni oglašen krivim zbog krivičnog dela nedozvoljeno držanje oružja i eksplozivnih materija iz čl. 348. st. 1. KZ jer je u svojoj kući neovlašćeno držao pištolj, neosnovani su navodi u žalbi branioca okrivljenog da je pomenuto delo malog značaja zbog niskog stepena krivice okrivljenog $\mathrm{i}$ odsustva štetnih posledica i da u radnji okrivljenog nema elemenata krivičnog dela, a shodno čl. $18 \mathrm{KZ}$. U konkretnom slučaju treba imati u vidu društvenu vrednost zaštićenog objekta - javni red i bezbednost ljudi i imovine, pa delo kojim se isti napada odnosno ugrožava ne može se smatrati delom malog značaja i izricanje krivične sankcije za takvo delo je nužno radi suzbijanja ovakvih delatnosti (Presuda Okružnog suda u Čačku K 85/05 od 13. januara 2006. i presuda Vrhovnog suda Srbije Kž 772/06 od 30. maja 2006) ${ }^{19}$.
${ }^{16}$ Isto.
${ }^{17}$ Isto.
${ }^{18}$ Isto.
${ }^{19}$ Isto. 
- Kada je okrivljeni oglašen krivim zbog izvršenja krivičnog dela prikrivanja iz čl. 184. st. 1. KZS jer je dobijao stvari od okrivljenih, a znao je da su te stvari pribavljene krivičnim delom teške krađe - obijanjem više kuća i vikendica oštećenih, onda nema mesta primeni čl. 8. st. 2. KZJ, a to je da nema krivičnog dela jer radnja okrivljenog predstavlja neznatnu društvenu opasnost zbog malog značaja i zbog neznatnosti ili odsutnosti štetnih posledica. (Presuda Opštinskog suda u Čačku K 176/1998. od 9. jula 2001. i presuda Okružnog suda u Čačku Kž 166/03 od 11. juna 2003) ${ }^{20}$.

- Iako je okrivljeni izvršio krivično delo samovlašća iz čl. 225. st. 1. KZS jer je samovlasno pribavio pravo naknade štete koja mu je pričinila privatna tužilja kao razvedeni bračni drug, tako što je iz njenog dela kuće oduzeo televizor, ima mesta primeni čl. 8. st. 2. KZJ i da se u konkretnom slučaju radi o neznatnoj društvenoj opasnosti, jer je oduzeti televizor zajednička tekovina stranaka, a po uzimanju te stvari je ostavio pismeno obaveštenje privatnoj tužilji da je upravo on to uradio i zašto je to uradio (Presuda Opštinskog suda u G. Milanovcu K 388/02 od 23. aprila 2003. i presuda Okružnog suda u Čačku Kž 214/03 od 18. juna 2003) ${ }^{21}$.

- Iako je okrivljeni izvršio krivično delo iz čl. 52a. Zakona o izgradnji objekata, jer je započeo gradnju ograde na svojoj građevinskoj parceli bez pribavljene građevinske dozvole ima se smatrati da krivično delo nije izvršeno jer isto predstavlja neznatnu društvenu opasnost zbog malog značaja i zbog neznatnosti ili odsutnosti štetnih posledica, s obzirom da je oko njegovog placa sa tri strane postojala ograda, a postavljanjem sporne ograde do javnog puta nije izazvalo reagovanje građana (Presuda Opštinskog suda u Čačku K 4/03 od 28. februara 2003. i presuda Okružnog suda u Čačku Kž 225/03 od 16. juna 2003) ${ }^{22}$.

- Kada je okrivljeni kao odgovorno lice potpisao dana (...) službenu ispravu sa neistinitom sadržinom, da jedan deo zdravstvenog centra je pripojen drugom delu, znajući da nije zasedao Upravni odbor i time izvršio krivično delo falsifikovanja službene isprave iz čl. 248. st. 3. u vezi st. 1. KZ, drugostepeni sud je primenio odredbu čl. 8. st. 2. OKZ jer je u međuvremenu zasedao Upravni odbor, i potpisana je službena isprava ali sada sa istinitom sadržinom jer je krivično delo malog značaja i odsutne su štetne posledice, a do pripajanja delova zdravstvenog centra je došlo (Presuda Opštinskog suda u G. Milanovcu K 335/03 od 1. aprila 2004. i presuda Okružnog suda u Čačku Kž $165 / 04$ od 2. juna 2004. $)^{23}$.

- Kada je prvookrivljeni izvršio krivično delo falsifikovanje službene isprave iz čl. 248, st. 3 , u vezi st. 1, KZS, a drugookrivljeni krivično delo
${ }^{20}$ Isto.
${ }^{21}$ Isto.
${ }^{22}$ Isto.
${ }^{23}$ Isto. 
falsifikovanje isprave iz čl. 233, st. 3, u vezi st. 1, KZS, tada se radi o povredi pravnog saobraćaja i službene dužnosti, pa nema uslova za primenu instituta neznatne društvene opasnosti predviđene u čl. 8. st. 2. OKZ (Presuda Opštinskog suda u G. Milanovcu K 121/05 od 25. aprila 2005. i rešenje Okružnog suda u Čačku Kž 254/05 od 6. jula 2005.) $)^{24}$.

- Krivično delo falsifikovanje službene isprave je krivično delo protiv službene dužnosti čiji je zaštitni objekat zakonitost rada. Posledica ovog dela je ugrožavanje pravilnog i zakonitog vršenja službenih ovlašćenja, pa stoga svesno i voljno nezakonito postupanje službenih lica ne može ovo krivično delo učiniti manje društveno opasnim jer se društvena opasnost ovog dela ne ogleda samo u posledici dela (Rešenje Okružnog suda u Nišu Kž 31/06 od 27. marta 2006) $)^{25}$.

- Rešenjem o odbijanju optužnog predloga za krivično delo neovlašćenog držanja opojnih droga iz čl. 245. st. 3. OKZ, prvostepeni sud je povredio Krivični zakon tako što se u primeni čl. 8. st. 2. navedenog zakona rukovodio samo vrstom i količinom opojne droge koju je okrivljeni neovlašćeno držao, a nije ocenio da li je delo malog značaja i da li su posledice dela neznatne ili odsutne (Rešenje Vrhovnog suda Srbije Kž 620/05 od 21. aprila 2005) ${ }^{26}$.

- Ocenu o tome da li neovlašćeno držanje opojne droge u konkretnom slučaju predstavlja delo malog značaja treba dati na osnovu rezultata glavnog pretresa, a ne u postupku prethodnog ispitivanja optužnog akta (Rešenje Vrhovnog suda Srbije Kž 1435/06 od 26. septembra 2006) ${ }^{27}$.

- U slučaju izvršenja krivičnog dela iz čl. 149. Zakona o planiranju i izgradnji, nema mesta primeni čl. 18. KZ, jer u konkretnom slučaju je okrivljeni izgradio dva građevinska objekta na prostoru Nacionalnog parka „Tara”, a bez uticaja je činjenica što pomenuti objekti nisu legalizovani, a što može uticati samo na poseban upravni postupak (Presuda Apelacionog suda u Kragujevcu Kž 1536/10 od 11. marta 2010) ${ }^{28}$.

- Kod izvršenja krivičnog dela iz čl. 245. KZS ne može se raditi o krivičnom delu malog značaja s obzirom na propisanu kaznu zatvora za to delo, niti se radi o neznatnosti i odsutnosti štetnih posledica budući da je u pitanju droga koja deluje razorno na zdravlje i radnu sposobnost ljudi i dovodi do teških zdravstvenih problema, pa čak i smrti, a i socijalnih problema - konflikata u porodici, bekstva iz porodice i drugo pri čemu i količina od 40 grama marihua-

\footnotetext{
${ }^{24}$ Isto.

${ }^{25}$ Paragraf Lex - pravna baza.

${ }^{26}$ Isto.

${ }^{27}$ Isto.

${ }^{28}$ Isto.
} 
ne nije mala i neznatna (Presuda Vrhovnog suda Srbije Kž 246/05 od 23. maja $2006)^{29}$.

- Sud mora prilikom utvrđivanja da li je u konkretnoj krivičnoj stvari posledica krivičnog dela krađe neznatna u smislu instituta delo malog značaja, uzeti u obzir i kvalitet - vrednost stvari koje je predmet krađe (Presuda Okružnog suda u Subotici Kž 509/07 od 25. januara 2008) ${ }^{30}$.

- Kada okrivljeni, u vreme protestnih demonstracija Demokratske opozicije Srbije 5. oktobra 2000. g., iz Skupštine SRJ oduzmu dve stolice, čija je knjigovodstvena vrednost nula, ispunjeni su uslovi za primenu instituta neznatne društvene opasnosti (Presuda Okružnog suda u Beogradu Kž 810/02 od 8. maja 2002. i presuda Prvog Opštinskog suda u Beogradu K 521/01 od 1. novembra 2001) ${ }^{31}$.

- Prilikom ocene društvene opasnosti dela zbog malog značaja treba ceniti i ličnost izvršioca krivičnog dela (Rešenje Okružnog suda u Beogradu Kž 1983/04 od 24. septembra 2004. i rešenje Četvrtog opštinskog suda u Beogradu K 660/04 od 31. maja 2004) ${ }^{32}$.

- Kod ocene društvene opasnosti krivičnog dela iz čl. 245. st. 3. OKZ nije dovoljno vrsta i količina opojne droge već i druge okolnosti, kao kvalitet vinosti i značaj zaštićenog dobra, a sve u vezi sa primenom čl. 8. st. 2. OKZ (Presuda Vrhovnog suda Srbije Kž 696/06 od 18. aprila 2006) ${ }^{33}$.

- Držanje jedne tablete ekstazija za svoje potrebe, na muzičkoj manifestaciji, ako su ispunjeni svi drugi uslovi može predstavljati delo malog značaja (Presuda Vrhovnog suda Srbije Kž 1493/05 od 25. oktobra 2005) . $^{34}$.

- Ne može se uzeti da predstavlja neznatnu društvenu opasnost zbog ma$\log$ značaja i zbog odsutnosti štetnih posledica - čl. 8. st. 2. OKZ, takva radnja izvršenja krivičnog dela koja se sastoji u tome što je okrivljeni 12. aprila 2003. kupio 10 evra, a pri sebi je imao tri puta veći dinarski iznos novca, a dana 20. novembra 2003. kupio 100 evra, a dokazima je utvrđeno da je kontinuirano na ulici prodavao i kupovao devize i vikao „euro, euro” (Presuda Opštinskog suda u Subotici K 926/03 od 20. aprila 2005. i presuda Okružnog suda u Subotici Kž 304/05 od 20. jula 2005.) $)^{35}$.

- Optužni predlog se može odbaciti ako delo u pitanju po zakonu nije krivično delo i ako sadrži obeležja krivičnog dela određena zakonom, iz razloga

\footnotetext{
${ }^{29}$ Isto.

${ }^{30}$ Isto.

${ }^{31}$ Ilija Simić: Zbirka sudskih odluka iz krivične materije, V knjiga, 2004.

${ }^{32}$ Isto, VII knjiga, 2005.

${ }^{33}$ Bilten sudske prakse Okružnog suda u Novom Sadu broj 10/06 - Intermeks - pravna baza.

${ }^{34}$ Isto, br. 12/07 - Intermeks - pravna baza.

${ }^{35}$ Poslovna politika - Sudska praksa broj 3-4/07.
} 
što predstavlja neznatnu društvenu opasnost zbog malog značaja i zbog neznatnosti štetnih posledica s obzirom da je okrivljeni samovlasno iz kase studentskog kluba oduzeo novčane bonove za koje je smatrao da mu pripadaju, a čija vrednost je iznosila 548,00 dinara (Rešenje Okružnog suda u Beogradu Kž 2092/92 od 9. 12. 1992) ${ }^{36}$.

- Kada je okrivljeni u svom ekonomskom dvorištu kao poljoprivrednik napravio, bez odobrenja za izgradnju čardak za smeštaj kukuruza i time su ostvarena obeležja krivičnog dela iz čl. 149. st. 2. Zakona o planiranju i izgradnji, ima se osloboditi od optužbe primenom čl. 8. st. 2. OKZ jer preduzete radnje predstavljaju neznatnu društvenu opasnost zbog malog značaja i zbog neznatnosti štetnih posledica (Presuda Opštinskog suda u B. Topoli K 177/05 od 16. decembra 2005. i presuda Okružnog suda u Subotici Kž 44/06 od 6. februara 2006) ${ }^{37}$.

- Napuštanje jedinice u vreme povećanog stepena borbene gotovosti predstavlja delo velikog, a ne malog značaja, posebno ako je učinjeno od strane aktivnog vojnog lica, pri čemu značaj ovog dela ne može umanjiti ni okolnost da je okrivljeni pre samovoljnog napuštanja jedinice podneo molbu za prestanak aktivne vojne službe (Presuda Vrhovnog vojnog suda K 350/00 od 5. jula 2000) ${ }^{38}$.

- Kada je okrivljeni oglašen krivim zbog krivičnog dela nedozvoljeno držanje oružja i eksplozivnih materija iz čl. 348. st. 1. KZ jer je u svojoj kući neovlašćeno držao pištolj, neosnovani su navodi u žalbi branioca okrivljenog da je pomenuto delo malog značaja zbog niskog stepena krivice okrivljenog $\mathrm{i}$ odsustva štetnih posledica, pa da u radnji okrivljenog nema elemenata krivičnog dela shodno čl. 18. KZ (Presuda Vrhovnog suda Srbije Kž 772/06 od 30. maja 2006) $)^{39}$.

- Pravilno je prvostepeni sud ocenio da se radi o delu malog značaja s obzirom na to da je stepen krivice okrivljenog nizak, a imajući u vidu količinu manju od 0,01 gr heroina koja je pronađena kod okrivljenog, da isti ne ostavlja štetne posledice, odnosno da se radi o neznatnim štetnim posledicama po zdravlje onog koji konzumira navedenu količinu heroina, te da opšta svrha krivičnih sankcija ne zahteva izricanje krivične sankcije (Presuda Vrhovnog suda Srbije Kž 1045/09 od 8. 9. 2009) .

- Zahtev za zaštitu zakonitosti Republičkog javnog tužioca je osnovan, pa se utvrđuje da je pravnosnažnom presudom Apelacionog suda u Kragujevcu

\footnotetext{
${ }^{36}$ Glosarijum - Izbor sudske prakse, broj 7-8/1993.

${ }^{37}$ Poslovna politika - Sudska praksa, broj 7-8/06.

${ }^{38}$ Glosarijum - Izbor sudske prakse, broj 10/2001.

${ }^{39}$ Isto, broj 2/07.

${ }^{40}$ Bilten Okružnog suda u Kraljevu, broj 4/09 - Intermeks - pravna baza.
} 
Kž 109/10 od 14. aprila 2010. povređen Zakon u korist okrivljenog - čl. 368. st.1. t.11, čl. 391. st. 1. ZKP i čl. 18. st. 1. i 2. KZ.

Iz obrazloženja:

Presudom drugostepenog suda preinačena je presuda prvostepenog suda kojom je okrivljeni oglašen krivim zbog krivičnog dela zloupotreba službenog položaja iz čl. 359. st.1. KZ tako što se okrivljeni oslobađa od optužbe da je izvršio pomenuto krivično delo primenom čl. 355. st. 1 t. $1 \mathrm{ZKP} \mathrm{u} \mathrm{vezi} \mathrm{čl.} \mathrm{18.} \mathrm{KZ.}$

Iz obrazloženja drugostepene presude je nejasno da li je i zbog čega stepen krivice učinioca nizak imajući u vidu da je okrivljeni postupao u svojstvu policajca kao službenog lica i koliko i iz kojih razloga opšta svrha krivičnih sankcija ne zahteva izricanje krivične sankcije u konkretnom slučaju, a što su kumulativni uslovi za primenu čl. 18. st. 2. KZ koji u konkretnom slučaju nisu bili ispunjeni. Posebno zbog toga što se okrivljenom stavlja na teret da nije izvršio službenu radnju, a što je bio dužan na osnovu čl. 164. Zakona o bezbednosti saobraćaja na putevima a to je da napiše prekršajnu prijavu i sačini zapisnik o izvršenom pregledu (Presuda Apelacionog suda u Kragujevcu Kž 1009/10 od 14. aprila 2010. i presuda Vrhovnog kasacionog suda Srbije Kzz $177 / 10$ od 10 . novembra 2010$)^{41}$.

${ }^{41}$ Arhiva Višeg javnog tužilaštva u Čačku. 